\title{
KARAKTERISASI KONDISI KIMIA-FISIKA LINGKUNGAN PADA TINGKATAN DENSITAS MANGROVE YANG BERBEDA DI AMPALLAS, KABUPATEN MAMUJU, SULAWESI BARAT \\ Characterization of Chemical-Physical Environmental Conditions at Density Levels of Different Mangrove in Ampallas, Mamuju Regency, West Sulawesi
}

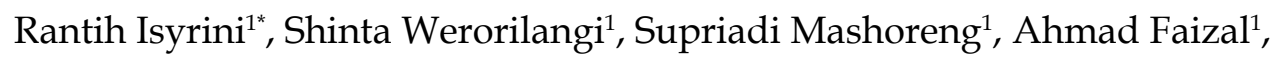 \\ Akbar Tahir ${ }^{1}$, Rastina Rachim ${ }^{1}$
}

Diterima: 26 Mei 2017 Disetujui: 15 Juni 2017

\begin{abstract}
Mangroves have numerous ecological functions as well as economical values. In order to achieve successful of mangrove restoration and regain its functions, understanding on the factors affecting the establishment of mangroves are required. This study examined the characteristics of physico-chemical factors from three compartments (sediment, interstitial and seawater) that associated with different mangrove densities in Ampallas, District of Mamuju, West Sulawesi. The Principal Component Analysis and Spearman correlation analysis showed that high densities of adult and seedling mangroves strongly correlated to higher organic contents, dissolved oxygen of interstitial water, seawater salinities and lesser $\mathrm{pH}$ of sediments, seawater and interstitial. The reverse conditions applied for the less mangrove densities and control site that had no mangrove. In most cases, there were reciprocal relationships amongst the studied variables.
\end{abstract}

Keywords: chemical-physical factors, density, mangroves.

\section{PENDAHULUAN}

Indonesia merupakan penyumbang terbesar luas mangrove dunia (19\%) dengan luas sekitar 2,9juta hektar mangrove pada tahun 2005. Jumlah luas mangrove tersebut berkurang dari total luas 4,2 hektar di tahun 1980 (FAO, 2007). Penurunan jumlah luas lahan mangrove disebabkan oleh beragam sebab, diantaranya konversi ekosistem mangrove ke tambak, perkebunan, ataupun perumahan, serta pencemaran. Berkurangnya jumlah lahan mangrove di Indonesia menjadikan ekosistem mangrove tidak optimum lagi dalam mengkontribusikan peranan baik ke lingkungan sekitar maupun pada manusia.

Upaya restorasi lahan mangrove telah banyak dilakukan di berbagai lokasi, akan tetapi seringkali berakhir dengan hasil yang tidak optimum bahkan kegagalan. Beberapa penelitian telah dilakukan untuk melihat faktor-faktor yang berpengaruh terhadap keanekaragaman/komposisi spesies dan distribusi mangrove (Duke et al., 1998; Marchand

1 Departemen Ilmu Kelautan, Universitas Hasanuddin

* Rantih Isyrini

Email: risyrini@yahoo.com et al., 2004) ataupun zonasi (Ahmed and AbdelHamid, 2007). Namun, pengetahuan mengenai faktor-faktor lingkungan yang mempengaruhi kerapatan mangrove semaian maupun dewasa sangat sedikit. Lingkup kompartemen/ media pun sangat terbatas. Beberapa variabel telah diketahui mempengaruhi pertumbuhan mangrove, seperti: suhu, konsentrasi nitrogen pada tanah dan kandungan organik pada tanah (Hastuti et al., 2016).

Untuk memperoleh gambaran yang lengkap mengenai faktor-faktor lingkungan yang mempengaruhi kerapatan mangrove semaian dan dewasa, penelitian ini mencakup pengujian variabel lingkungan pada tiga kompartemen, yaitu pada sedimen, air interstisial maupun air laut.

Penelitian ini dilakukan pada ekosistem mangrove di Ampallas, Mamuju, Sulawesi Barat yang merupakan kawasan semi konservasi dan memiliki densitas mangrove yang beragam. Pencirian kondisi lingkungan yang diperoleh pada densitas mangrove yang berbeda di Ampallas, Kabupaten Mamuju, Sulawesi Barat merupakan langkah dasar dalam upaya penemuan parameter-parameter kunci 


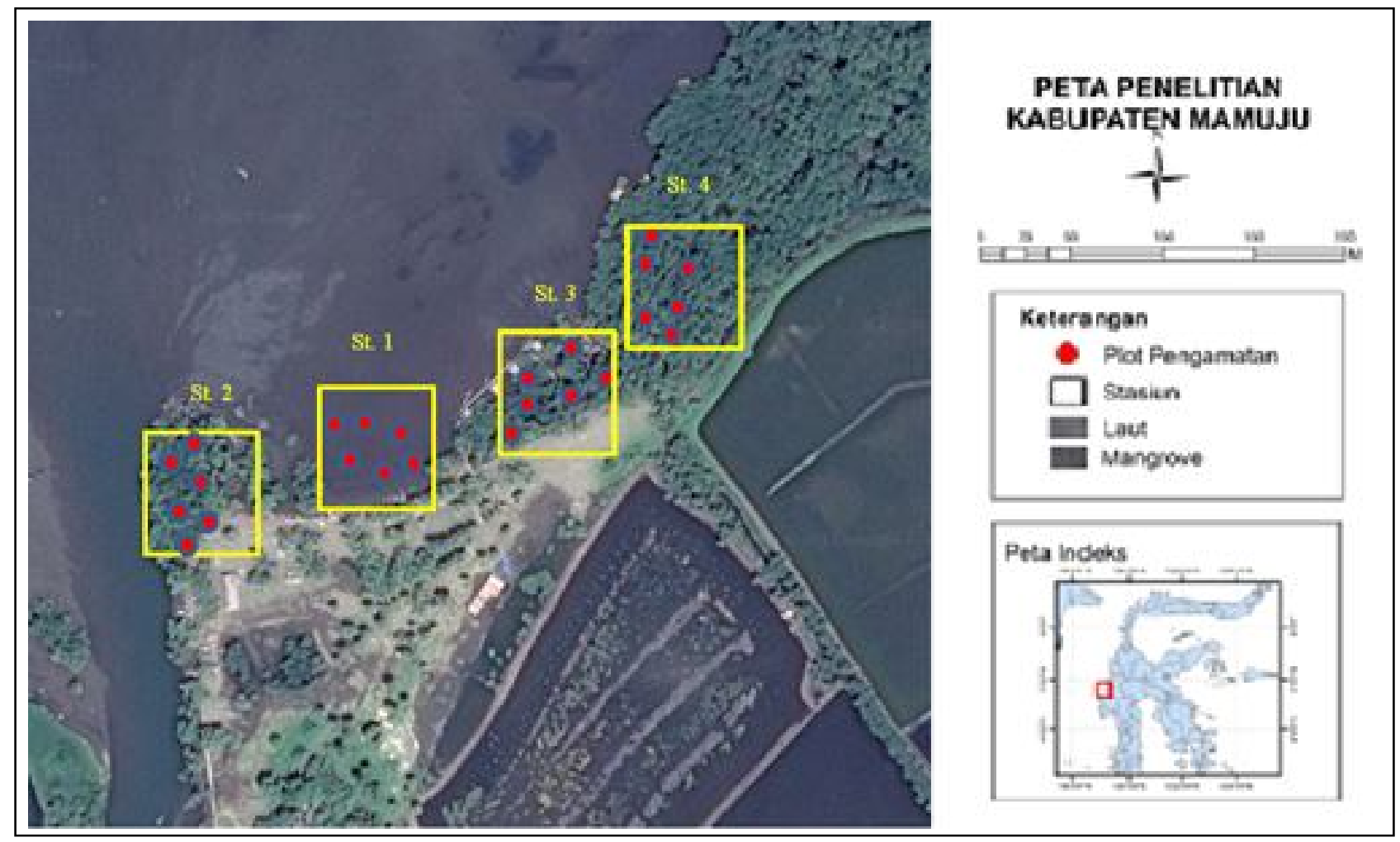

Gambar 1. Lokasi Penelitian di Ampallas, Kabupaten Mamuju, Sulawesi Barat.

yang dapat digunakan dalam upaya restorasi mangrove sehingga pengembalian fungsi ekosistem mangrove yang optimal pada daerahdaerah lain dapat dicapai.

Penelitian ini bertujuan untuk mengetahui kondisi kimia-fisika yang mencirikan tingkatan densitas mangrove semaian dan dewasa di Ampallas, Kabupaten Mamuju, Sulawesi Barat. Hasil penelitian bermanfaat untuk melengkapi pengetahuan demi terwujudnya usaha restorasi mangrove yang sukses sehingga ekosistem mangrove dapat menjalankan fungsinya dengan optimum.

\section{METODE PENELITIAN}

Penelitian ini dilakukan pada bulan MeiAgustus 2016 di Ampallas, Kabupaten Mamuju, Provinsi Sulawesi Barat.

Penelitian ini dilaksanakan di empat stasiun yang memiliki tingkatan densitas mangrove yang berbeda. Jumlah kerapatan mangrove ditentukan dengan mengkonversi jumlah mangrove di dalam plot berukuran $10 \times 10 \mathrm{~m} 2$ ke satuan ha. Stasiun 1 yang tidak memiliki mangrove berfungsi sebagai stasiun control. Stasiun 2 memiliki mangrove yang rendah (583 mangrove/ha). Stasiun 3 ditumbuhi oleh mangrove dengan tingkatan sedang (1100 mangrove/ha). Sementara stasiun 4 memiliki tingkatan mangrove yang padat (1750 mangrove/ha). Pada setiap stasiun, dipilih enam pohon mangrove dewasa yang memiliki tinggi dan diameter yang sama serta penampakan kesehatan yang sama sebagai obyek penelitian.

Sampel permukaan sedimen $(0-5 \mathrm{~cm}$ dari permukaan) diambil pada jarak satu meter dari setiap pohon mangrove dewasa yang telah ditentukan sebagai objek penelitian.

Serupa dengan sedimen permukaan, air interstitial diambil dengan menggunakan botol peeping yang terbuat dari sebuah botol berukuran $250 \mathrm{ml}$ yang pada bagian bawahnya dihubungkan dengan pipa PVC. Pipa ini berfungsi untuk menahan botol sehingga tetap tegak di dalam sedimen secara kuat. Pada bagian atas botol, dilubangi mengelilingi botol dan ditutupi dengan kain kasa yang berfungsi meminimasi sedimen masuk ke dalamnya.

Botol peeping ini diletakkan pada lubang di sedimen dan ditanam saat surut dan disimpan semalaman untuk memastikan air interstial masuk ke dalam botol. Keesokan harinya, botol peeping diangkat dan airnya ditransfer ke dalam botol sampel secepatnya. Pada sekeliling bagian atas botol memiliki lubang-lubang yang 


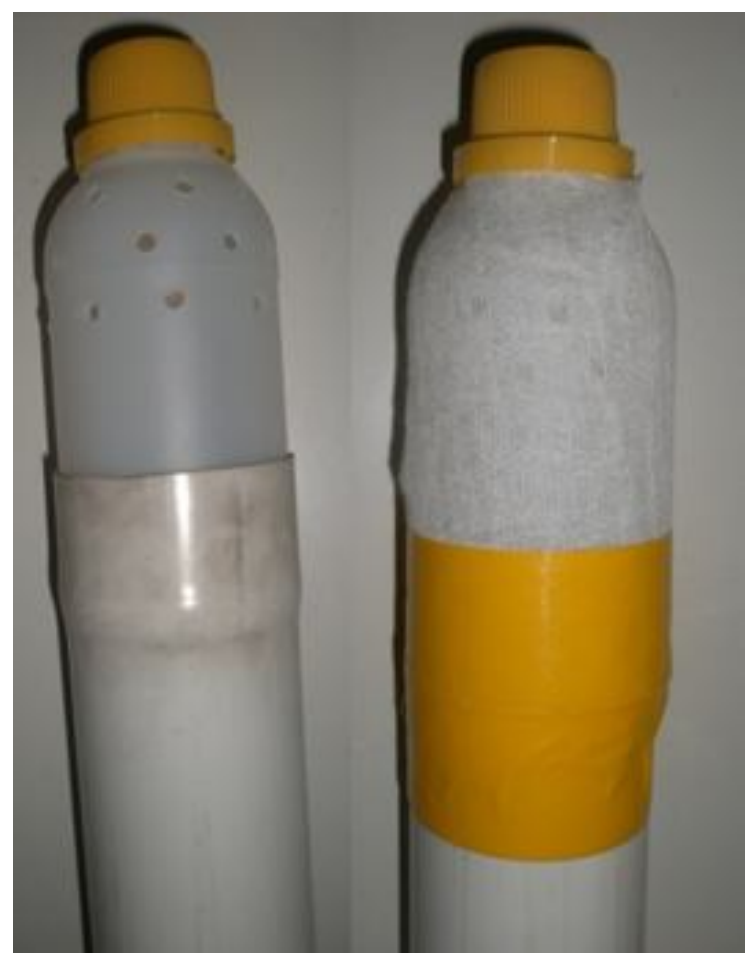

Gambar 2. Botol peeping didesain untuk mengambil sampel air interstitial di ekosistem mangrove

dilapisi dengan kasa lembut dan bagian bawah dihubungkan dengan pipa PVC.

Sementara, sampel air laut diambil pada saat sebelum air surut dan dimasukkan dengan menggunakan botol sampel berukuran 250 ml. Seluruh sampel dimasukkan ke dalam cool box yang berisikan es dan dipindahkan ke refrigerator saat sampai ke laboratorium.

Penentuan $\mathrm{pH}$ dan redox potensial (Eh) pada sedimen permukaan dilakukan secara langsung dengan menggunakan $\mathrm{pH}$ meter dan Eh meter. Penentuan persentasi bahan organik total dilakukan dengan menggunakan metode Loss on Ignition (LOI) (Heiri et al., 2001), dimana $4 \mathrm{~g}$ sampel dipanaskan pada suhu $105 \mathrm{oC}$ selama 24 jam dan berat sampel diukur. Kemudian, berat sedimen diukurlagi setelah memanaskan sampel pada suhu 550oC selama 4 jam. Kandungan bahan organik ditentukan dengan memakai persamaan berikut:

\section{Dimana:}

$$
\mathrm{LOI}_{550}=\left(\left(\mathrm{BK}_{105}-\mathrm{BK}_{550}\right) / \mathrm{BK}_{105}\right) \times 100
$$

$$
\begin{aligned}
\mathrm{LOI}_{450}= & \text { LOI pada suhu } 550^{\circ} \mathrm{C} \text { (dalam } \\
& \text { persentase) } \\
\mathrm{BK}_{105}= & \begin{array}{l}
\text { berat kering dari sampel sebelum } \\
\text { pembakaran (dalam gr) }
\end{array} \\
\mathrm{BK}_{550}= & \begin{array}{l}
\text { berat kering dari sampel setelah } \\
\text { pemanasan dengan suhu } \\
\text { (dalam gr) }
\end{array}
\end{aligned}
$$

Ukuran butiran sedimen ditentukan dengan menggunakan metode pengayakan basah (Percival and Lindsay, 1997). Sebanyak $100 \mathrm{~g}$ sedimen diayak dengan menggunakan ukuran ayakan $63 \mu \mathrm{m}$ untuk menentukan persentase pasir, sementara persentase lempung dan liat ditentukan untuk butiran yang berukuran kurang dari $63 \mu \mathrm{m}$.

Beberapa analisis statistik digunakan dengan menggunakan software Excel dan SPSS. Enam replikasi digunakan untuk analisis statistik. Uji normalitas dilakukan untuk menentukan jenis analisis korelasi yang digunakan. Principal Component Analysis (PCA) digunakan untuk mengidentifikasi karakteristik kondisi kimia-fisika lingkungannya. Korelasi Spearman digunakan untuk mengevaluasi hubungan antara densitas mangrove dengan variabel kimia-fisika lainnya.

\section{HASIL DAN PEMBAHASAN}

\section{Kerapatan dan Komposisi Jenis Mangrove}

Nilai rata-rata kerapatan mangrove dewasa di lokasi penelitian berkisar 0 - 1750 mangrove/ ha. Ekosistem mangrove pada lokasi penelitian didominasi oleh mangrove dari genus Rhizophoraceae, yaitu Rhizophora mucronata dan R. apiculata.

Stasiun 1 yang berlaku sebagai stasiun kontrol, tidak ditumbuhi oleh mangrove. Stasiun 2 memiliki total rata-rata kerapatan mangrove dewasa sebesar 583 mangrove/ha. Stasiun ini didominasi oleh $R$. apiculata sebanyak 300 mangrove/ha. Stasiun 3 dengan rata-rata total kerapatan mangrove dewasa sebesar 1100 mangrove/ha, didominasi oleh $R$. mucronata sebanyak 967 mangrove/ha. Stasiun 4 dengan rata-rata total kerapatan mangrove dewasa sebesar 1750 mangrove/ha, didominasi oleh $R$. mucronata sebanyak 1417 mangrove/ha.

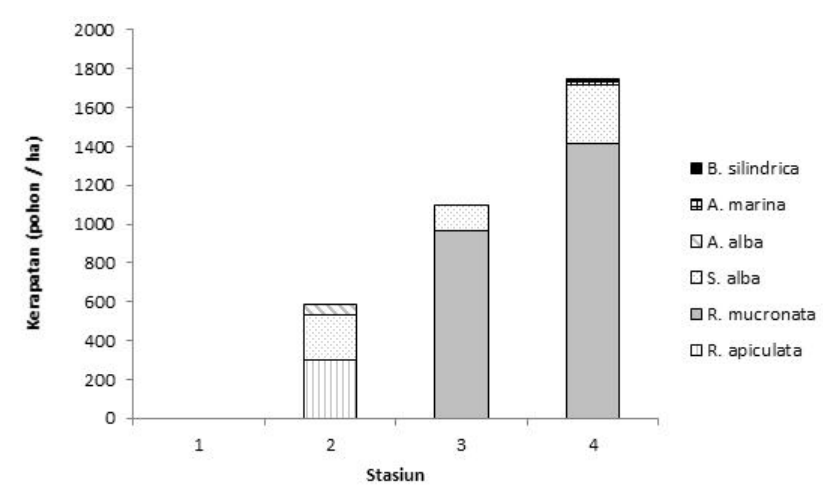

Gambar 3. Diagram kerapatan dan komposisi jenis mangrove dewasa di Ampallas, Mamuju 
Sementara rata-rata kerapatan mangrove semaian berkisar antara 0 - 400 semaian/ha. Jenis semaian yang tumbuh di lokasi penelitian hanya berupa $R$. mucronata yang juga mendominasi jenis mangrove dewasa.

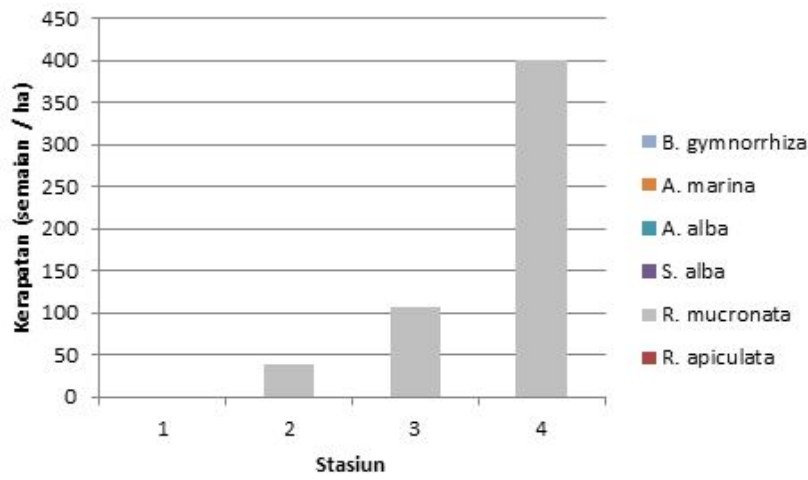

Gambar 4. Diagram kerapatan dan komposisi jenis mangrove semaian di Ampallas, Mamuju

\section{Kondisi Kimia-fisika Lingkungan}

$\mathrm{pH}$ sedimen pada lokasi penelitian tergolong alkalis, yaitu: 6,83-7,14. Hal ini menunjukkan besarnya pengaruh air laut pada sedimen. Stasiun 1 yang tidak ditumbuhi mangrove memiliki $\mathrm{pH}$ tertinggi. Nilai potensial redoks pada lokasi penelitian berkisar antara -73,2 $15,8 \mathrm{mV}$ yang menunjukkan bahwa sedimen berada dalam kondisi tereduksi.

Nilai rata-rata persentase bahan organik total berkisar 1,41-12,97 \%, di mana stasiun 4 memiliki bahan organik dengan persentase tertinggi. Secara umum, sedimen pada lokasi penelitian didominasi oleh pasir dengan persentase pasir berkisar 95,79-98,24\% dan persentase lempung/liat berkisar 0,4-2,78 \%, dimana stasiun 1 memiliki persentase pasir tertinggi dan lempung/liat terendah.

Tabel 1. Kondisi fisika-kimia sedimen pada ekosistem mangrove di Ampallas, Mamuju.

\begin{tabular}{cccccc}
\hline $\begin{array}{c}\text { Sta- } \\
\text { siun }\end{array}$ & pH & Eh & $\begin{array}{c}\text { Bahan } \\
\text { Organik (\%) }\end{array}$ & Pasir (\%) & $\begin{array}{c}\text { Lempung } \\
\text { Liat (\%) }\end{array}$ \\
\hline 1 & $7,14+0,32$ & $-23+66,3$ & $1,41+0,78$ & $98,24+1,62$ & $0,64+0,94$ \\
2 & $6,83+0,26$ & $15,8+107,3$ & $3,23+2,56$ & $95,79+3,39$ & $2,78+2,04$ \\
3 & $6,89+0,21$ & $-13,4+74,9$ & $3,06+1,51$ & $97,38+1,82$ & $2,06+1,51$ \\
4 & $6,71+0,10$ & $-73,2+113,6$ & $12,97+6,61$ & $96,51+1,33$ & $2,12+1,61$ \\
\hline
\end{tabular}

Jumlah rata-rata oksigen terlarut pada air interstisial di lokasi penelitian berkisar 4,3 - 7,1 ppm, dimana jumlah rata-rata oksigen terlarut berada pada stasiun $4 . \mathrm{pH}$ air interstisial juga tergolong alkalis yang berkisar antara 6,59 7.10, dimana $\mathrm{pH}$ tertinggi berada pada stasiun 1. Salinitas air interstisial pada lokasi penelitian berada dalam rentang 25 - 29\%o (Tabel 2).

Tabel 2. Kondisi fisika-kimia air interstitial pada ekosistem mangrove di Ampallas, Mamuju.

\begin{tabular}{cccc}
\hline Stasiun & $\begin{array}{c}\text { Oksigen } \\
\text { Terlarut (ppm) }\end{array}$ & $\mathbf{p H}$ & $\begin{array}{c}\text { Salinitas } \\
\mathbf{( \% )}\end{array}$ \\
\hline 1 & $5,8+1,0$ & $7,10+0,05$ & $25+2$ \\
2 & $4,3+1,5$ & $6,59+0,09$ & $23+3$ \\
3 & $6,6+0,1$ & $6,79+0,05$ & $29+2$ \\
4 & $7,1+0,2$ & $6,8+0,11$ & $25+3$ \\
\hline
\end{tabular}

Kadar oksigen terlarut pada air laut di lokasi penelitian berkisar 5,9- 7,0 ppm, dimana kadar oksigen terendah berada pada stasiun 1. $\mathrm{pH}$ air laut di stasiun-stasiun serupa dan bersifat alkalis $(7,13-7,63)$. Salinitas air laut berkisar antara 13 - 30(\%o), dimana stasiun 1 dan 2 memiliki kadar garam terendah karena lokasinya yang dipengaruhi oleh air sungai, sementara stasiun 3 dan 4 berkadar garam yang tinggi akibat pengaruh dari air laut (Tabel 3).

Tabel 3. Kondisi kimia-fisika air laut pada ekosistem mangrove di Ampallas, Mamuju.

\begin{tabular}{cccc}
\hline Stasiun & $\begin{array}{c}\text { Oksigen } \\
\text { Terlarut (ppm) }\end{array}$ & pH & $\begin{array}{c}\text { Salinitas } \\
(\%)\end{array}$ \\
\hline 1 & $5,9+0,5$ & $7,63+0,03$ & $13+4$ \\
2 & $7,0+0,3$ & $7,39+0,04$ & $15+3$ \\
3 & $6,4+0,8$ & $7,40+0,16$ & $26+2$ \\
4 & $6,3+0,7$ & $7,13+0,09$ & $30+3$ \\
\hline
\end{tabular}

Karakteristik Kondisi Kimia-Fisika Lingkungan

Gambar 5 memperlihatkan bahwa stasiun 4 yang ditumbuhi oleh mangrove dengan kerapatan mangrove dewasa dan semaian yang tinggi (padat) dicirikan dengan tingginya bahan organik total, oksigen terlarut interstisial, salinitas air laut, serta rendahnya $\mathrm{pH}$ sedimen, $\mathrm{pH}$ air laut dan $\mathrm{pH}$ interstial. Hal yang sebaliknya berlaku untuk stasiun dengan kerapatan mangrove yang jarang atau tidak ada. 


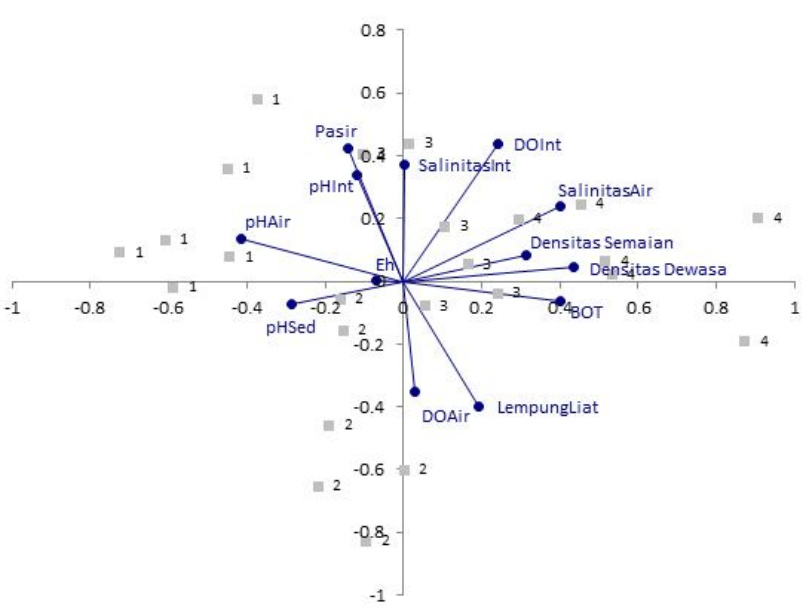

Gambar 5. Karakteristik Kondisi Kimia Fisika Lingkungan pada ekosistem Mangrove di Ampallas, Mamuju.

Analisis Korelasi Spearman (Tabel 4) memperkuat PCA dimana analisis menunjukkan bahwa kerapatan mangrove dewasa yang tinggi (padat) berhubungan kuat dengan rendahnya $\mathrm{pH}$ air laut $(\mathrm{r}=-0,830 ; \mathrm{p}<0,01)$ dan sedimen $(\mathrm{r}$ $=-0,603 ; \mathrm{p}<0,01)$, salinitas air laut yang lebih tinggi $(\mathrm{r}=0,841 ; \mathrm{p}<0,01)$, bahan organik total yang tinggi $(r=0,727 ; p<0,01)$ serta kandungan oksigen air interstisial yang cenderung tinggi $(r$ $=0,656 ; \mathrm{p}<0,01$ ).

Selaras dengan kerapatan dewasa, analisis Korelasi Spearman juga menunjukkan bahwa kerapatan mangrove semaian memiliki korelasi kuat dengan beberapa faktor di atas. Kerapatan mangrove semaian memiliki hubungan yang kuat dengan rendahnya $\mathrm{pH}$ air laut $(\mathrm{r}=-0,472 ; \mathrm{p}$ $<0,05)$, salinitas air laut yang cenderung tinggi ( $\mathrm{r}$ $=0,483 ; p<0,05)$, bahan organik total yang tinggi $(\mathrm{r}=0,523 ; \mathrm{p}<0,05)$ serta kandungan oksigen air interstisial yang relatif tinggi $(r=0,441 ; p<0,05)$. Kerapatan mangrove semaian juga memiliki hubungan dengan persentase pasir yang rendah $(\mathrm{r}=-0,435 ; \mathrm{p}=0.05)$ serta kerapatan mangrove dewasa yang tinggi $(r=0,667 ; p=0,01)$.

Salah satu faktor kimia-fisika lingkungan yang berhubungan sangat kuat dengan tingginya kerapatan mangrove dewasa dan semaian pada lokasi adalah bahan organik. Tingginya bahan organik terutama pada stasiun yang memiliki kerapatan mangrove dewasa yang tinggi (stasiun 4) disebabkan oleh banyaknya serasah yang dihasilkan oleh bagian-bagian mangrove, utamanya dedaunan yang jatuh ke sedimen. Banyaknya serasah berpotensi untuk menjadi humus yang tentunya berguna baik bagi perkembangan semaian maupun mangrove dewasa. Hal ini ditandai dengan kuatnya korelasi antara kerapatan mangrove dewasa dan semaian serta bahan organik total. Akar Rhizophora and Avicennia menahan/ menyimpan sekitar 83-92\% dedaunan yang membusuk yang berpotensi menghasikan nutrien (Gillis et al., 2016).

Tabel 4. Korelasi Spearman mengenai hubungan densitas mangrove dewasa dan semaian dengan kondisi kimia-fisika lingkungan di lokasi penelitian

\begin{tabular}{|c|c|c|c|c|c|c|c|c|c|c|c|c|}
\hline & $\begin{array}{c}\text { Eh } \\
\text { Sed }\end{array}$ & $\begin{array}{l}\mathrm{pH} \\
\text { Sed }\end{array}$ & BOT & Pasir & $\begin{array}{l}\text { DO } \\
\text { Int }\end{array}$ & $\begin{array}{l}\mathrm{pH} \\
\text { Int }\end{array}$ & $\begin{array}{l}\text { Salinitas } \\
\text { Int }\end{array}$ & $\begin{array}{l}\text { DO } \\
\text { Air }\end{array}$ & $\begin{array}{l}\mathrm{pH} \\
\text { Air }\end{array}$ & $\begin{array}{l}\text { Salinitas } \\
\text { Air }\end{array}$ & $\begin{array}{c}\text { Dens } \\
\text { Dewasa }\end{array}$ & $\begin{array}{c}\text { Dens } \\
\text { Semaian }\end{array}$ \\
\hline Eh Sed & 1 & -0.226 & -0.363 & 0.182 & -0.201 & -0.086 & -0.111 & 0.001 & 0.263 & -0.221 & -0.186 & -0.072 \\
\hline pHSed & & 1 & -0.227 & 0.091 & -0.384 & $.435^{*}$ & 0.013 & -0.125 & $.447^{*}$ & $-.592^{* *}$ & $-.603^{* *}$ & -0.129 \\
\hline BOT & & & 1 & $-.638^{* *}$ & $.442^{*}$ & -0.094 & -0.142 & 0.082 & $-.820^{* *}$ & $.525^{\star *}$ & $.727^{* *}$ & $.523^{* *}$ \\
\hline Pasir & & & & 1 & 0.104 & 0.148 & 0.302 & -0.191 & 0.372 & 0.02 & -0.285 & $-.435^{*}$ \\
\hline DO Int & & & & & 1 & 0.266 & 0.31 & -0.332 & $-.507^{*}$ & $.815^{\star *}$ & $.656^{* *}$ & $.441^{*}$ \\
\hline pH Int & & & & & & 1 & 0.119 & $-.594^{* *}$ & 0.376 & -0.186 & -0.299 & -0.046 \\
\hline Salinitas Int & & & & & & & 1 & -0.279 & 0.045 & 0.349 & 0.248 & 0.302 \\
\hline DO Air & & & & & & & & 1 & -0.305 & -0.15 & 0.186 & 0.069 \\
\hline pH Air & & & & & & & & & 1 & $-.694^{* *}$ & $-.830^{* *}$ & $-.472 *$ \\
\hline Salinitas Air & & & & & & & & & & 1 & $.841^{* *}$ & $.483^{*}$ \\
\hline Dens Dewasa & & & & & & & & & & & 1 & $.667^{* *}$ \\
\hline Dens Semaian & & & & & & & & & & & & 1 \\
\hline $\begin{array}{l}* * \text { Korelasi signi } \\
* \text { *. Korelasi sign }\end{array}$ & $\begin{array}{l}\text { ifikan } \\
\text { ifikan }\end{array}$ & $\begin{array}{l}\text { pada } t \\
\text { pada }\end{array}$ & $\begin{array}{l}\text { igkata } \\
\text { ngkata }\end{array}$ & $\begin{array}{l}0.01(2 \\
0.05(2\end{array}$ & $\begin{array}{l}\text { led). } \\
\text { iled). }\end{array}$ & & $\begin{array}{l}\text { Sec } \\
\text { Int } \\
\text { Air } \\
\text { De }\end{array}$ & $\begin{array}{l}: \\
: \\
: \\
:\end{array}$ & $\begin{array}{l}\text { sedimen } \\
\text { interstitia } \\
\text { air laut } \\
\text { densitas n }\end{array}$ & angrove & & \\
\hline
\end{tabular}


Selain BOT yang tinggi, mangrove dengan kerapatan yang tinggi dicirikan dengan oksigen terlarut air interstial yang tinggi. Hingga saat ini, masih sangat sedikit penelitian yang memasukkan variabel oksigen terlarut pada air interstial yang mempengaruhi mangrove. Hal yang diketahui adalah oksigen diperlukan oleh setiap tumbuhan, tidak terkecuali mangrove. Walaupun demikian, mangrove memiliki cara tersendiri dalam merespon oksigen yang rendah pada lingkungan yaitu melalui bentuk akarnya yang khas untuk memperoleh oksigen (Kathiresan and Bingham, 2001). Pada Rhizophora misalnya, dicirikan dengan akar penyangga yang secara struktur terdiri atas cabang horizontal dan kolom vertikal. Akar kolom vertikal berfungsi menyuplai oksigen ke akar bawah tanah melalui pori-pori kecil atau lenticel (Hogarth, 2007). Jika oksigen yang tersedia dalam akar melebihi dari yang dibutuhkan untuk respirasi, oksigen yang berlebihan dapat berdifusi menyeberangi dinding akar, terlepas ke sedimen sekitar, dan bereaksi dengan komponen tanah tereduksi (Sundby et al., 2003). Hal ini menunjukkan adanya hubungan timbal balik antara oksigen dan mangrove itu sendiri.

Berbeda dengan yang ditemukan beberapa peneliti lain (Saenger, 2002; Marchand et al., 2004) bahwa Rhizophora tumbuh pada area yang memiliki variabilitas aliran air tawar yang besar, Rhizophora dengan kerapatan yang padat (stasiun 4) pada lokasi penelitian dicirikan dengan salinitas air laut dan interstitial yang lebih tinggi dibanding dengan stasiun lain. Walaupun demikian, nilai rata-rata salinitas interstisial pada stasiun 4 tidak terlalu tinggi $(25+3)$ dibandingkan dengan stasiun lain yang memiliki salinitas air laut dan interstitial rendah akibat letaknya yang sangat dipengaruhi oleh aliran air tawar dari sungai. Relatif rendahnya salinitas air interstial pada stasiun 4 diakibatkan oleh aliran dari kali air tawar yang mendominasi saat surut.

Untuk beradaptasi dengan salinitas yang tinggi, Rhizophora memiliki ultrafilter di sistem perakarannya yang berfungsi menyaring garam (Kathiresan and Bingham, 2001).

Selain itu, stasiun dengan kerapatan mangrove yang padat dicirikan dengan $\mathrm{pH}$ sedimen, air laut dan interstitial yang relatif rendah dibanding stasiun lainnya. Relatif rendahnya $\mathrm{pH}$ (asam ringan) pada sedimen, air laut dan interstitial pada stasiun 4 yang memiliki kerapatan mangrove yang besar, tidak terlepas dari tingginya bahan organik pada stasiun tersebut. Dekomposisi bahan organik, ditambah dengan keberadaan sistem akar berserat pada Rhizophora yang membentuk lumpur semacam gambut membuat $\mathrm{pH}$ menurun setelah proses dekomposisi (Ahmed and Abdel-Hamid, 2007).

Tidak dapat dipungkiri bahwa kerapatan mangrove semaian yang besar didukung oleh ketersediaan sumber bibit (buah) mangrove yang banyak pada stasiun 4 yang memiliki kerapatan mangrove dewasa yang tinggi.

\section{KESIMPULAN}

Kesimpulan yang dapat diambil dari hasil penelitian adalah stasiun yang ditumbuhi oleh mangrove dengan kerapatan mangrove dewasa dan semaian yang tinggi (padat) dicirikan dengan tingginya bahan organik total, oksigen terlarut interstisial, salinitas air laut, serta rendahnya $\mathrm{pH}$ sedimen, $\mathrm{pH}$ air laut dan $\mathrm{pH}$ interstial. Sementara, stasiun dengan kerapatan mangrove yang jarang atau tidak ada berlaku hal sebaliknya. Pada kebanyakan variabel penelitian, terdapat hubungan timbal balik antar variabel. Ketersediaan sumber bibit berupa buah yang terdapat pada stasiun yang memiliki kerapatan mangrove dewasa yang tinggi juga merupakan faktor penting kerapatan semaian mangrove yang tinggi pula.

\section{DAFTAR PUSTAKA}

Ahmed, E. A. and Abdel-Hamid, K. A. 2007. Zonation Pattern of Avicennia marina and Rhizophora mucronata along the Red Sea Coast, Egypt. World Applied Sciences Journal, 2: 283-288.

Duke, N. C., Ball, M. C. and Ellison, J. C. 1998. Factors influencing biodiversity and distributional gradients in mangroves. Global Ecology and Biogeography Letters, 7: 2747.

FAO 2007. The World's Mangroves 1980-2005. Food and Agriculture Organization of the United Nations. Rome. Italy.

Gillis, L. G., Zimmer, M. and Bouma, T. J. 2016. Mangrove leaf transportation: Do mimic Avicennia and Rhizophora roots retain or donate leaves? Marine Ecology Progress Series, 551: 107-115. 
Hastuti, E. D., Anggoro, S. and Pribadi, R. 2016. Dynamic linkages of mangrove Rhizophora mucronata and its environment parameters in Semarang and Demak coastal area. International Journal of Applied Environmental Sciences, 11: 279-293.

Heiri, O., Lotter, A. F. and Lemcke, G. 2001. Loss on ignition as a method for estimating organic and carbonate content in sediments: reproducibility and comparability of results. Journal of Paleolimnology, 25: 101110.

Hogarth, P. 2007. The Biology of Mangroves and Seagrasses. Oxford University Press. New York, USA.

Kathiresan, K. and Bingham, B. L. 2001. Biology of mangroves and mangrove ecosystems. Advances in Marine Biology, 40: 81-251.
Marchand, C., Baltzer, F., Lallier-Vergés, E. and Albéric, P. 2004. Pore-water chemistry in mangrove sediments: relationship with species composition and developmental stages (French Guiana). Marine Geology, 208: 361-381.

Percival, J. B. and Lindsay, P. J. 1997. Chapter two. Measurement of physical properties of sediments. In Mudroch, A., Azcue, J. M., and Mudroch, P., editor. Manual of PhysicoChemical Analysis of Aquatic Sediments. CRC Press, Inc. Florida. USA.

Saenger, P. 2002. Mangrove Ecology, Silviculture and Conservation. Kluwer Academic Publishers. Netherlands.

Sundby, B., Vale, C., Caetano, M. and Luther, G. W. 2003. Redox Chemistry in the Root Zone of a Salt Marsh Sediment in the Tagus Estuary, Portugal. Aquatic Geochemistry, 9: 257-271. 